\title{
"Legislation Should Be the Voice of Reason"
}

\author{
NIKHIL GANGAPPA MANTUR* \\ Assistant Professor, Blde Law College, Jamkhandi \\ *Corresponding Author: NIKHIL GANGAPPA MANTUR, Assistant Professor, Blde Law College, \\ Jamkhandi
}

\begin{abstract}
Statute law or statutory law is a law that is created by the legislation. A statute is a formal act of the legislature in written form. A legislature is a kind of assembly with the power to pass, amend and repeal laws. Statutory laws are the basic framework of the modern legal system. Supreme legislation and subordinate legislation are two types of the legislature. Legislative powers are divided into three lists: Union list, State list, and concurrent list. Let us learn more about the types of the legislature and legislative powers. While legislation definition is given as a kind of assembly that has the power to amend, pass, and repeal laws.
\end{abstract}

\section{INTRODUCTION}

Legislation means the process of lawmaking. Legis means law and Latum mean "making", and as a whole it means lawmaking. According to Austin, it means the making of law by a supreme or a sovereign authority which must be followed by people of every stratum of the society. Salmond defines Legislation as the process of lawmaking by a competent and able authority. Legislation is the process of lawmaking where a competent authority is given the task of drafting and enacting the law in a state. It is also said to be a strict concept of lawmaking because there is only one body which is entrusted with the work of lawmaking and also there is no scope of any alteration as such because of codified and watertight laws which leave a very minuscule range of the amendment.

\section{DEFINITION OF LEGISLATION}

Salmond: "Legislation is that source of law which comprises in the assertion of lawful standards by a competent specialist."

Austin: "Legislation is the command of the sovereign or the superior authority which must be followed by the common masses backed by sanctions".

Gray states that, "Legislation implies the formal expression of the administrative organs of the general public."

Positivist School: "A run of the mill law is a rule and legislation is the typical source and form of lawmaking." Most examples of this school don't affirm that the courts additionally can figure law. They don't concede the case of custom as a wellspring of law. Consequently, they view just legislation as the form of law.

Historical School: "The legislation is the least innovative of the forms of law. The authoritative motivation behind the legislation is to give the better framework and increasingly viable the custom which is unexpectedly created by the general population." Historical School usually don't perceive the legislation as a form of law.

\section{TYPES OF LEGISLATION}

Legislation can have numerous reasons, for instance, to direct, to approve, to endorse, to give, to authorise, to allow, to proclaim, to confine and to annul. Therefore in enacting any legislation and the rule of law, the welfare of the citizens must be kept in mind and therefore, it is must be adopted in the best interests of the citizens.

Some different types of legislation are as follows:

\subsection{Supreme Legislation}


The Supreme legislation is the legislation adopted by the sovereign intensity of the state. In this manner, some other authorities which are the organ of the state cannot control or check it. It is considered incomparable as well as lawfully powerful. An established piece of this rule can be found in Dicey's book, 'The Law of the Constitution'. There is no legitimate restriction on its capacity. Indian parliament is likewise preeminent. Even though there are different constitutional amendments upon its capacity, it isn't subject to any other administrative authorities inside the state. Therefore the sovereign jurisdiction of the state can't be revoked, cancelled or constrained by some other authoritative organ of the state.

\subsection{Subordinate Legislation}

Subordinate legislation is any other legislation which is lower in authority from supreme legislation and derives its power from any authority other than the sovereign power. Whereas, legislation created by authorities like corporations, municipalities, universities under the authority of supreme legislation is part of subordinate legislation. The judiciary has been given legislative powers as well. Superior courts are allowed to make rules to regulate their own function and administration. The executive's main purpose is to enforce the law. It is also given legislative power in some cases to make rules. This type of subordinate legislation is also called executive or delegated legislation. Municipal corporate enjoy limited power that has been given by the legislation to make rules and bye-laws for areas under their jurisdiction. In certain cases, the State gives authority to autonomous bodies like universities to make their bye-laws which are enforced by a court of justice. However, the rule-making power of the executive is very limited in its scope. The rules made by the executive are placed on both the Houses of the Parliament and are then considered to be approved by the legislature. These rules then become part of the laws. When a conflict arises in relation to the validity of rules made the executive, courts have the authority to give judgement on any of the rules made by the executive so they do not exceed their authority delegated to them under the parent act.

\subsection{Legislative Powers}

The legislative powers of centre and state are clearly defined in the constitution. These powers are split into three different lists.

- Union List: The Union list consists of 100 items on which only the Parliament has exclusive powers legislation because of their concern to the Centre.

- State List: The State list consists of 61 items where the state legislative assembly has the authority to make laws that would be applicable in that particular state. However, under certain circumstances, the parliament also has legislative powers in matters of the state list.

- Concurrent List: The Concurrent List consists of 52 items where both the parliament and the state legislature have the authority to make their own laws under their own domains because it concerns both the parties.

\subsection{Colonial Legislation}

The nations which are not autonomous, and are under the control of some other state have no Supreme capacity to make law. Such countries can be in different classes such as colonies, domains, secured or trust regions and so forth. The laws made by them are subject to the Supreme legislation of the state under whose control they are. Therefore it is subordinate legislation. England has had numerous colonies and territories. The laws made by them for the self-government are subject to modification, nullification or supersession by the legislation of the British Parliament. As the colonies are free, accomplished freedom and practically all the British domains have an unlimited power for legislation, hence sooner rather than later, we might have this class of subordinate legislation no more in existence.

\subsection{Executive Legislation}

At the point when legislative powers are delegated by the designated official to an executive, it is called executive legislation. Even though the significant capacity of the official is to execute the laws and carry on the organisation, he/she is continuously dependent on some subordinate enactment powers. Today, for all intents and purposes of each law sanctioned by the lawmaking body contains assignment statements giving law-making powers by the official to the executive in order to enhance the statutory arrangements. 


\subsection{Judicial Legislation}

Powers delegated to the judicial system to make and implement their own laws to maintain transparency in the judicial system of the country. This will also ensure that there is no involvement of any other organ of the government in the governance of the judicial system of the state.

\subsection{Municipal Legislation}

Municipal bodies are offered powers to make bye-laws concerning their neighbourhood matters. Bye-law made by a neighbourhood body works inside its individual area. In India, such municipal bodies are Municipal corporations, Municipal Boards, Zila Parishads, and so on. There is a move for allowing extensive powers to Panchayats. Along these lines, there is a plausibility of extension of this sort of subordinate enactment in our nation. Balwant Rai committee appointed by the Parliament gave some parliamentary reforms needed in the Panchayat system of the country. The recommendations were later on incorporated in the Constitution by 73rd Amendment.

\subsection{Autonomous Legislation}

At the point when the Supreme authority gives powers upon a gathering of people to administer on the issues depended to them as a gathering, the law made by the last is known as the autonomous law and the body is known as a self-ruling body. A railway is an independent body. It makes bye-laws for the guideline of its organisation, and so on. A college is likewise a self-governing body. Even some universities in India have been granted the status of autonomous bodies.

\subsection{Delegated Legislation}

- Delegated (subordinate or subsidiary) Legislation alludes to those laws made by people or bodies to whom parliament has delegated law-making powers.

- Where Acts are made by Parliament, a Principal Act may cause arrangement for Subsidiary Legislation to be made and will to indicate who can make laws as such under that Act.

- Delegated Legislation can just exist in connection to an empowering or parent Act.

- Delegated Legislation contains the numerous regulatory subtleties essential to guarantee that the arrangements of the Act will work effectively. It might be directed by Government Departments, Local Councils or Courts.

- Guidelines and Statutory Rules are the most widely recognised types of Delegated Legislation. They are made by the Executive or a Minister which apply to the overall public. By-laws, and once in a while Ordinances are made by a Local Government Authority which also applies to the general population who live around there. Principle and Parent Act regularly depict methodology to be followed in Courts if there is any flaw in a delegated law.

\section{Sub-Delegation}

It is also a case in Indian Legal system. The power to make subordinate legislation is derived from existing enabling act. It is fundamental that the delegate on whom such power is conferred has to act within the limits of the enabling act. Its purpose is to supplant and not to supplement the law. Its main justification is that sometimes legislature does not foresee the difficulties that will come while enacting the law. Therefore, Delegated Legislation fills in those gaps which are not seen while the formulation of the enabling act. Delegated Legislation gives flexibility to law and there is ample scope for adjustment in the light of experiences gained during the working of legislation.

\section{Advantages of Legislation as a Source OF LAW}

Verifiably additionally the legislation has dependably been perceived as a significant wellspring of law as contrasted and different sources. There are two apparent explanations behind the legislation is viewed as a standout amongst the most significant sources of law. Right off the bat, it includes setting down of legitimate principles by the lawmaking bodies which the State perceives as law. Besides, it has the power and authority of the State. It is hence said by Dias and Hughes that conscious law-production by a legitimate power, i.e. the State is called 'legislation' which gave that sovereign is correctly perceived as the supreme power by the courts. Relative Merit of Legislation over Precedent and customs have been discussed below. 


\subsection{Some Main Advantages of Legislation Are as Follows}

Abrogative Power-It can change or annul old law, which control isn't controlled by different sources.

Effectiveness-It separates the elements of making law and overseeing it between the Legislature and the legal executive.

Declaration - It gives that principles of law will be known before they are authorised.

Reliance on Accidental Legislation - Legislation is independent and emerges out of as the authoritative source of law it need not hold up until the original case of legislation.

Unrivalled in Form - It is predominant in structure, brief, clear, effectively available and understandable as against case law, which is an increase of sense in a considerable amount of pointless issue.

\section{Legislation ANd PRECEDENT}

The legislation has its source in the process of law which is basically enacted and enforced by the State while the precedent has its origin in ancient and historic judicial pronouncements.

Legislation has an authoritative force on courts by the assembly. However, precedents are made by the courts themselves.

Legislation signifies formal declaration of law by the governing body though precedents are acknowledgement and use of new standards of law by courts in the administration of equity, justice and good conscience.

Legislation is ordered before a case emerges. However, the precedent appears simply after the case has developed and taken for the choice of the court.

Legislation is basically of an exhaustive structure while the extent of legal precedent is restricted to comparable cases as it were.

Legislation is commonly and generally forthcoming while precedent is retrospective in nature.

Legislation is announced or distributed before it is brought into power, on the other hand, precedent comes into power on the double, i.e. when the choice is articulated.

Legislation is finished with the goal of the lawmaking process yet it isn't so on account of the precedent. The precedent which incorporates ratio decidendi and obiter dicta are expected to settle a particular contest on the purpose of law once for all.

It isn't hard for people, in general, to realise the law instituted by lawmaking body yet the precedent dependent on the case law isn't effectively known to the general population. Now and again, the attorneys who manage law are themselves oblivious about the current case-law. Therefore it makes a precedent of an ambiguous nature.

Legislation includes law-production by deductive strategy while case-law is made by resorting to an inductive technique.

\section{LEGISLATION AND CUSTOM}

The presence of legislation is basically by law, while customary law is wholly accepted in a particular boundary.

Legislation is enacted out of hypothetical standards. However, customary law becomes is adopted because of its very well and long presence in history.

Legislation as a source is indeed a long lasting nature of law, as contrasted to the custom which is the most established type of law and is followed by a particular sect.

The legislation is a fundamental characteristic for a present-day society while the customary law was created in a crude social order.

Legislation is finished, exact, written in the structure and effectively open. However, customary law is generally unwritten am non-scriptum and is hard to follow. 
Legislation results out of the deliberations while custom develops inside the general public in the ordinary course.

\section{DEMERITS OF LEGISLATION}

There is no source of law which is perfect and totally complete in its form and sense, some lacunas and loopholes could be easily found in every source of law which is as follows in the case of legislation.

Unbending nature - Law in the legislation is inflexible though the law in the precedents is versatile and adaptable

In view of Hypothesis - Legislation, for the most part, continues on speculative certainties, by considering the existing environment and surrounding in which the established law is frequently observed to be blemished in its application to the mind-boggling issues emerging in genuine life though piecescratches develop out of the commonsense exigencies and convenience.

An excessive amount of Importance to the Wordings - Legislation appends a lot of significance to its wordings. Thus, if the articulation is faulty, the law in itself gets effectively turned. In the precedents, the wording matters close to nothing as there is a genuine introduction which performs separate checks on the applicability of precedent as a source of law. Same goes with the customary law as well.

\section{THE RELATIONSHIP BETWEEN LAW AND SOCIETY}

Theorists have traditionally maintained that there are certain broad views on the substantive criminal law. One set of such constraints concerns the sorts of behaviour that may legitimately be prohibited. Is it proper, for example, to criminalize a certain kind of action on the grounds that most people in one's society regard it as immoral? The other set of constraints which concern what is needed in order to establish criminal responsibility that is liability, independently of the content of the particular statute whose violation is in question. Legal system reflects all the energy of life within in any society. Law has the complex vitality of a living organism. We can say that law is a social science characterized by movement and adaptation. Rules are neither created nor applied in a vacuum, on the other hand they created and used time and again for a purpose. Rules are intended to move us in a certain direction that we assume is good, or prohibit movement in direction that we believe is bad. The social rules are made by the members of the society. Disobedience of the social rules is followed by punishment of social disapproval. There is no positive penalty associated with the violation of rules except excommunication or ostracism. On the other hand, law is enforced by the state. The objective of law is to bring order in the society so the members of society can progress and develop with some sort of security regarding the future. The state makes laws. Disobedience of state laws invites penalty, which is enforced by the government by the power of the state. What is not enforceable is not Law.

\section{IMPORTANCE OF LAW IN SOCIETY}

The law is important for a society for it serves as a norm of conduct for citizens. It was also made to provide for proper guidelines and order upon the behaviour for all citizens and to sustain the equity on the three branches of the government. It keeps the society running. Without law there would be chaos and it would be survival of the fittest and everyman for himself. Not an ideal lifestyle for most part. The law is important because it acts as a guideline as to what is accepted in society. Without it there would be conflicts between social groups and communities. It is pivotal that we follow them. The law allows for easy adoption to changes that occur in the society. Society is a 'web-relationship' and social change obviously means a change in the system of social relationship where a social relationship is understood in terms of social processes and social interactions and social organizations. Thus, the term, 'social change' is used to indicate desirable variations in social institution, social processes and social organization. It includes alterations in the structure and functions of the society. Closer analysis of the role of law vis-àvis social change leads us to distinguish between the direct and the indirect aspects of the role of law.

1. Law plays an important indirect role in regard to social change by shaping a direct impact on society. For example: A law setting up a compulsory educational system.

2. On the other hand, law interacts in many cases indirectly with basic social institutions in a manner constituting a direct relationship between law and social change. For example, a law designed to prohibit polygamy. 
Law plays an agent of modernization and social change. It is also an indicator of the nature of societal complexity and its attendant problems of integration. Further, the reinforcement of our belief in the ageold panchayat system, the abolition of the abhorable practices of untouchability, child marriage, sati, dowry etc are typical illustrations of social change being brought about in the country trough laws. Law is an effective medium or agency, instrumental in bringing about social change in the country or in any region in particular. Therefore, we rejuvenate our belief that law has been pivotal in introducing changes in the societal structure and relationships and continues to be so.

Law certainly has acted as a catalyst in the process of social transformation of people wherein the dilution of caste inequalities, protective measures for the weak and vulnerable sections, providing for the dignified existence of those living under unwholesome conditions etc. are the illustrious examples in this regard. Social change involves an alteration of society; its economic structure, values and beliefs, and its economic, political and social dimensions also undergo modification. However, social change does not affect all aspects of society in the same manner.

While much of social change is brought about by material changes such as technology, new patterns of production, etc., other conditions are also necessary. For example, as we have discussed it before, legal prohibition of untouchability in free India has not succeeded because of inadequate social support. Nonetheless, when law cannot bring about change without social support, it still can create certain preconditions for social change. Moreover, after independence, the Constitution of India provided farreaching guidelines for change. Its directive principle suggested a blueprint for a new nation. The derecognition of the caste system, equality before the law and equal opportunities for all in economic, political and social spheres were some of the high points of the Indian Constitution.

\section{CONCLUSION}

Legislation is therefore regarded as the most important source of law in the prevalent times. Hence it is considered to be the codified form of law which is commanded by the sovereign to the common masses, and it becomes a predicament situation to regard legislation as the authoritative source of law. Legislation is one of the foremost and most important source of law in today's world. Most countries in today's world regard legislation as an essential source of law and follow this system of lawmaking. Although some lacunae and loopholes are there which exists in the present form but then too the difficulties such faced are relatively less than that faced from the other sources of law viz. custom and precedent as legislation as a source of law tries to bring uniformity by avoiding the ambiguity.

\section{REFERENCES}

[1] https://www.toppr.com/guides/business-laws-cs/introduction-to-law/principle-sources-indian-law-statutelegislation/

[2] https://www.toppr.com/guides/legal-aptitude/jurisprudence/sources-of-law-legislation/

[3] https://blog.ipleaders.in/legislation-source-law/

[4] ibid

[5] https://blog.ipleaders.in/legislation-source-law/

[6] https://www.toppr.com/guides/business-laws-cs/introduction-to-law/principle-sources-indian-law-statutelegislation/

[7] https://blog.ipleaders.in/legislation-source-law/

[8] https://blog.ipleaders.in/legislation-source-law/

[9] https://www.legalbites.in/law-notes-administrative-law-legislation-types/

[10] https://blog.ipleaders.in/legislation-source-law/

[11] https://blog.ipleaders.in/legislation-source-law/

[12] https://legaldesire.com/article-importance-of-law-in-society/

[13] https://legaldesire.com/article-importance-of-law-in-society/

Citation: NIKHIL GANGAPPA MANTUR. "Legislation Should Be the Voice of Reason" International Journal of Political Science (IJPS), vol 6, no.3, 2020, pp. 21-26. doi: https://doi.org/10.20431/2454-9452.0603003.

Copyright: (C) 2020 Authors. This is an open-access article distributed under the terms of the Creative Commons Attribution License, which permits unrestricted use, distribution, and reproduction in any medium, provided the original author and source are credited. 